KAMASEAN: JURNAL TEOLOGI KRISTEN

Volume 1, No 2, Desember 2020; (92-106) Available at:http://kamasean.iakn-toraja.ac.id

\title{
Teologi Pernikahan Kristen Sebagai Kritik Etis Teologis Terhadap LGBT
}

\author{
James A. Lola \\ Institut Agama Kristen Negeri (IAKN) Toraja \\ Jnlola86@gmail.com
}

\begin{abstract}
One of the issues that has become the subject of debate theologically or ethically is LGBT, through literature research, the author tries to provide an understanding of Christian marriage theology that is in accordance with Bible principles to be used as a criticism of the views that accept LGBT to be legalized in the Church.
\end{abstract}

Keywords: LGBT, Bible, Christian Marriage

\begin{abstract}
Abstrak: Salah satu isu yang telah menjadi pokok perdebatan baik secara teologis maupun secara etis adalah LGBT, melalui penelitian literatur, penulis mencoba untuk memberikan pemahaman mengenai teologi pernikahan Kristen yang sesuai dengan prinsip-prinsip Alkitab untuk dijadikan kritik terhadap pandangan yang menerima LGBT untuk dilegalkan dalam Gereja.
\end{abstract}

Kata Kunci: LGBT, Alkitab, Pernikahan Kristen,

$\begin{array}{llll}\text { Article History : } & \text { Received: 28-10-2020 } & \text { Revised: 30-12-2020 } & \text { Accepted: 30-12-2020 }\end{array}$

\section{Pendahuluan}

Salah satu persoalan yang cukup mengundang banyak perdebatan baik dalam konteks lokal di Indonesia maupun secara global adalah persoalan Lesbian, Gay, Bisexual dan Transgender (selanjutnya disingkat LGBT). ${ }^{1}$ Hal tersebut dipicu oleh banyaknya fenomena pemberitaan maupun aktivitas dari anggota LGBT itu sendiri dan yang semakin membuat persoalan ini menjadi persoalan yang ramai diperbincangkan adalah karena kemudian persoalan ini diangkatnya sebagai wacana dalam media-media populer menjadi sebuah isu yang populer .

Sebenarnya masalah LGBT ini sudah cukup lama mengemuka dan menjadi perdebatan yang cukup panjang, dari tahun $1960^{2}$ sampai pada periode tahun 2005

1 Persoalan ini tidak hanya menjadi perdebatan di antara kaum agamawan, namun juga telah menyentuh bidang-bidang yang lain misalnya persoalan etis, persoalan kesehatan dan ilmu pengetahuan serta persoalan Hak Asasi Manusia (HAM). Akronim LGBT sendiri merupakan singkatan dari Lesbian, Gay, Biseksual dan Transgender, ada juga yang menambah dengan istilah Queer sehingga akronimnya menjadi LGBTQ. Akronim ini sendiri mulai dipergunakan pada tahun 1990 untuk menggantikan istilah 'komunitas gay'.

${ }^{2}$ Bagi beberapa pihak perdebatan mengenai LGBT ini sebenarnya sama tua dengan sejarah kitab suci (terutama berkaitan dengan kisah Sodom dan Gomora, namun menjadi perdebatan dalam ranah yang lebih luas pada tahun 1960, ketika kaum LGBT (hampir seluruh Eropa) secara tegas menuntut kesamaan hak dengan warga negara lainnya tanpa membedakan orientasi seksualnya. Berlanjut di Amsterdam, pada tanggal 4 Mei 1970 Aksi Kelompok gay Muda Amsterdam (Amsterdamse Jongeren Aktiegroep Homoseksualiteit) melakukan aksi peringatan nasional untuk para korban meninggal akibat kekerasan yang dialami korban homoseksual. Pada bulan Mei 1979, dicetuskan dari ide anggota Center for Culture 
ketika pemerintahan Perancis dan menyusul negara-negara yang lain memberikan legitimasi dan pengesahan untuk pernikahan sejenis. ${ }^{3}$

Di Indonesia, LGBT mendapatkan juga perhatian dan tanggapan yang sangat beragam. Hal ini terlihat dari perdebatan-perdebatan yang terjadi di media sosial semisal Facebook, Twitter, bahkan tidak jarang telah dilakukan begitu banyak seminar dan kegiatan-kegiatan yang bertemakan LGBT. Pokok utama dari berbagai pendapat yang ada adalah bahwa LGBT dianggap tidak sesuai dengan kebudayaan dan kepercayaan (agama-agama) yang ada di Indonesia, meskipun harus diakui bahwa ada juga sekelompok orang yang menyetujui agar LGBT dapat diterima di Indonesia. ${ }^{4}$

Kontroversi mengenai LGBT di Indonesia, tidak hanya bersentuhan dengan dengan persoalan Hak Asasi Manusia dan persoalan kesehatan, tetapi lebih daripada itu persoalan ini menyentuh juga pada ranah yang lebih mendalam yaitu pada budaya, norma dan juga asas negara yang berlandaskan pada Pancasila, bahkan secara langsung pada hal yang lebih privasi yaitu agama.

Dalam ranah kekristenan sendiri, LGBT menjadi sebuah fenomena dan persoalan yang cukup serius, karena harus diakui bahwa sejak abad pertama, sejak Gereja berdiri, hal-hal ini telah mendapatkan perhatian juga dalam Kitab Suci dan Gereja mula-mula.

Pada umumnya dalam kekeristenan ditemukan dua sudut pandang berkaitan dengan LGBT yaitu "Pro-LGBT" dan "Anti-LGBT". Untuk yang pro-LGBT, memulai sudut pandang mereka dengan melandaskan kepada beberapa hal yaitu:

1. Pengalaman, bahwa kesadaran atau keberadaan mereka sebagai seorang LGBT adalah sebuah keadaan yang tidak dapat ditolak karena tanpa mereka sadari bahwa mereka telah berada dalam sebuah komunitas/ keadaan seperti yang saat ini.

2. Alasan Sains, yang dimaksud di sini bahwa keadaan LGBT merupakan sebuah keadaan yang terbawa dari lahir atau genetik, dan sangat resistant untuk dirubah karena dapat merusak mental dan daya hidup dari penganut LGBT

3. Secara filosofis bahwa pembawaan dari genetika/ biologis itu secara tidak langsung mempengaruhi perilaku mereka, sehingga perilaku LGBT adalah sesuatu yang sangat 'natural'.

4. Kitab suci, melihat bahwa sebenarnya tidak ada sebuah landasan alkitabiah yang cukup kuat, yang dapat dipakai untuk memberikan argumentasi atau landasan etis bagi penolakan terhadap LGBT, baik dalam sebuah pembacaan Alkitab secara sederhana (literal) maupun dalam bentuk sebuah penafsiran berdasarkan

and Recreation sebuah organisasi lesbian yang didirikan pertama kali di Amsterdam tahun 1946 untuk mendirikan sebuah monument peringatan bagi kaum homoseksual yang bekerja sama dengan kelompok gay dari Partai Sosialist Pasifist (The Gay Group of The Pasifist Socialist Party). Ide ini mendapat dukungan dari kelompok gay dan lesbian, baik dari individu maupun kelompok yang terdiri dari 7152 group lesbian dan gay juga dukungan dan antusiasme dari dunia internasional.

3 Di antara negara-negara itu adalah Kanada, Swedia, Finlandia, beberapa negara di Eropa dan negara bagian Amerika Serikat

4 Penolakan terhadap LGBT ini tidak hanya datang dari golongan masyarakat keagamaan, tetapi juga telah menyentuh kepada golongan elite dari para pemimpin bangsa yang dengan tegas menolak LGBT, bahkan menyesalkan keputusan badan kesehatan dunia yang memberikan bantuan dana untuk mensosialisasikan gerakan LGBT ini. lih. https://news.detik.com/berita/3141202/ketua-komisi-viii-dprkritik-bantuan-undp-untuk-lgbt-di-indonesia, diakses pada tanggal 20 Februari 2020 
kepada teori-teori penafsiran, bahkan menurut mereka, penolakan terhadap LGBT dianggap sebagai sesuatu yang lebih kejam dari penghukuman kekal. ${ }^{5}$

Sedangkan bagi mereka yang menolak LGBT, argumentasi mereka di bangun dengan titik tolak yang berbeda dengan pro-LGBT, karena jikalau yang pro-LGBT mendasarkan pada pengalaman dan menempatkan kitab suci pada bagian terakhir, justru anti-LGBT memulainya dari kitab suci:

1. Kitab suci, bahwa sebenarnya kitab suci telah memberikan kepada kita sebuah landasan yang cukup kuat berkaitan dengan hal tersebut, bahkan dapat dikatakan bahwa sebenarnya kitab suci juga melarang kita untuk bergaul dengan orang-orang tersebut, meskipun harus diakui bahwa tidak ada kata yang cukup representatif untuk menggambarkan LGBT seperti penjelasan Lance di atas, namun analogi terdekat yang seringkali digunakan untuk menggambarkan tentang hal ini adalah pada persoalan "incest' dalam Perjanjian Lama dan Poligami dalam Perjanjian Baru.

2. Secara Filosofi, bahwa proses penciptaan manusia (laki-laki dan perempuan) dengan natur yang berbeda memberikan sebuah legitimasi bahwa tindakan LGBT adalah sebuah tindakan abnormal

3. Secara Sains, bahwa LGBT telah memberikan sumbangan masalah kesehatan yang cukup tinggi misalnya penyakit menular seksual dan menyebabkan tingkat depresi yang cukup tinggi.

4. Pengalaman, adanya para penganut LGBT yang mengalami reorientasi (konversi) dari keadaan mereka.

Kedua model pendekatan ini, pada akhirnya menyebabkan polemik mengenai LGBT dalam kekristenan terus menjadi perdebatan yang panjang, karena kedua model pendekatan ini saling menegasi satu dengan yang lain, bagi Pro-LGBT pendekatan Scriptural yang dikembangkan oleh Anti-LGBT adalah sebuah pendekatan yang tidak memperhatikan 'masa kini' dan cenderung mengambil sikap yang arogan. Sebaliknya bagi yang Anti-LGBT, menilai bahwa pendekatan dari yang pro-LGBT adalah pendekatan yang penuh dengan kecurigaan terhadap kitab suci sebagai kebenaran absolut.

Mencermati gambaran ringkas mengenai perbedaan pendekatan di atas, maka dapat disimpulkan bahwa kedua model/ metode pendekatan di atas adalah sah secara ilmu pengetahuan. Tetapi dari sudut pandang Iman Kristen, pendekatan yang seharusnya lebih diutamakan adalah pendekatan yang lebih menekankan logika dan konsistensi konsep 'pemikiran Kristen'. Dalam hal ini presaposisi yang harus melandasi adalah presaposisi-presaposisi yang dibangun di atas dasar kitab suci sebagai sebuah norma yang tertinggi.

Persoalan lain yang muncul berkaitan dengan isu ini, bukan hanya pada tataran penempatan kitab suci sebagai landasan berpikir tetapi pada tataran hermeneutis juga, yang dimaksud di sini adalah berkaitan dengan penafsiran terhadap ayat-ayat kitab suci yang berkaitan dengan LGBT. Bagi beberapa orang penafsiranya yang mendiskrimasi LGBT sebagai sebuah dosa adalah penafsiran yang sangat arogan, ini terlihat dalam penjelasan Dale Martin, bahwa "Setiap penafsiran kitab suci yang menyakitkan orang, menindas orang, atau menghancurkan orang-orang tidak bisa menjadi interpretasi yang tepat, tidak peduli seberapa tradisional, bersifat historis ataupun dengan metode eksegetis yang benar"6.

5 Dale B. Martin, “Arsenokoitês and Malakos: Meanings and Consequences," in Ethics \& Homosexuality: Listening to Scripture, ed. Robert L. Brawley (Louisville, KY: John Knox Press, 1996), 11718

${ }^{6}$ Martin. 130 
Pandangan ini akhirnya melahirkan berbagai macam bentuk tafsiran dalam pembacaan kitab suci, yang akhirnya melahirkan berbagai paradigma berpikir dan bersikap yang juga beragam di dalam komunitas Gereja. Gereja dalam hal ini orang percaya secara tidak langsung dituntut untuk dapat memberikan pandangan dan mengambil sikap yang tegas berkaitan dengan LGBT, yang berdasarkan kepada pembacaan Kitab Suci, Apa sebenarnya yang dikatakan oleh kitab suci tentang LGBT dan bagaimana seharusnya Gereja bersikap terhadap mereka yang ada dalam komunitas LGBT.

Karena dalam pembacaan kitab suci seperti yang dijelaskan di atas, dinyatakan bahwa sebenarnya tidak ada satu katapun di dalam Alkitab baik dalam bahasa Ibrani maupun Bahasa Yunani yang ekuivalen untuk menggambarkan LGBT ini, karena LGBT adalah sebuah persoalan yang lebih kompleks. Memang ada pernyataan tentang tindakan homoseksual di dalam Alkitab, tetapi tidak ada komentar tentang homoseksualitas atau orientasi seksual secara per se. Jadi konteks budaya dan konseptual yang ada pada saat ini sangat berbeda dari Alkitab, ini merupakan salah satu faktor yang tidak bisa diabaikan. ${ }^{7}$ Bahkan, perubahan pandangan Alkitab tentang perbudakan, peran perempuan, dan perceraian/ pernikahan kembali memberikan sebuah lisensi hermeneutis untuk mengembangkan perspektif baru tentang praktek LGBT.

Bahkan di akhir-akhir ini, Gereja juga dituntut untuk tidak melakukan diskriminatif bagi mereka yang adalah LGBT, dan Gereja di minta untuk bukan hanya menerima mereka sebagai komunitas yang sama dengan yang lain, melainkan juga menyetujui dan melegalkan LGBT dengan cara memberikan sakramen pernikahan kudus terhadap pasangan-pasangan LGBT. ${ }^{8}$

\section{Metode Penelitian}

Penelitian ini menggunakan metode penelitian literatur (penelitian kepustakaan), ${ }^{9}$ penulis mengadakan studi literatur yang ada dan menganalisis data tersebut secara sistematis. Sedangkan metode penulisan yang dipakai adalah metode deskriptif analisis. Dikatakan deskriptif karena pertama akan digambarkan secara sistematis topik yang diselidiki baru kemudian dianalisis sifat fenomena tersebut. ${ }^{10}$

\section{Hasil Dan Pembahasan}

\section{LGBT, Apa Itu?}

Sebelum membahas lebih jauh tentang berbagai perspektif tentang LGBT, penulis akan mencoba memberikan terlebih dahulu penjelasan tentang apa sebenarnya yang

7 H. Darrell Lance, "The Bible and Homosexuality," American Baptist Quarterly 8, no. 2 (1989): 140-141.

${ }^{8}$ Persekutuan Gereja-Gereja Indonesia (PGI) telah mengeluarkan semacam surat penggembalaan (Pastoral) pada tanggal 28 Mei 2016, namun pernyataan Pastoral ini juga memicu perdebatan di kalangan Gereja, karena pada isi suratnya secara garis besar menyatakan bahwa Gereja-Gereja di Indonesia belum dapat menerima pernikahan sejenis namun menerima keberadaan LGBT sebagai bagian dari ciptaan Allah yang perlu dihargai hak dan kewajibannya

${ }^{9}$ Sugiyono, Metode Penelitian Kombinasi (Bandung: Alfabeta, 2015).

10 ibid 
dimengerti tentang istilah Lesbian, Gay, Bisexual dan Transgender. Memahami secara benar tentang apa yang dimaksud dengan Lesbian, Gay, Bisexual dan Transgender akan lebih mempermudah pembahasan dan kajian terhadapnya.

Ada cukup beragam pandangan mengenai apa sebenarnya yang dimaksud dengan LGBT, ada yang berpendapat bahwa yang dimaksud dengan LGBT di sini bukan merujuk hanya kepada sebuah perilaku seksual tetapi lebih kepada orientasi seksual, berdasarkan kepada pemisahan akan 'perilaku' dan 'orientasi' inilah maka menimbulkan banyak pendapat dan perdebatan berkaitan dengan LGBT.

LGBT dipahami bukanlah sebuah perilaku yang berkaitan dengan tindakan atau perilaku seksual misalnya sodomi melainkan lebih dipahami sebagai sebuah orientasi seksual yang dalam hal ini lebih berkaitan dengan perasaan ketertarikan secara seksual terhadap pasangan sejenis yang belum tentu melakukan tindakan seksual seperti yang disebutkan di atas.

Bagi yang pro terhadap LGBT menyatakan bahwa mereka yang anti terhadap LGBT telah salah dalam memaknai apa yang dimengerti secara benar terhadap LGBT sehingga menimbulkan mispersepsi dalam perdebatan akan hal-hal ini.

Sebenarnya LGBT baik yang dimengerti sebagai orientasi seksual ataupun perilaku seksual adalah hal yang sama, ${ }^{11}$ tetapi yang perlu dibedakan di sini adalah bahwa LGBT tidak harus dimaknai semata-mata pada perilaku yang biasa di sebut 'waria atau banci'. Karena LGBT lebih kompleks dari sekedar perilaku yang seperti itu. LGBT lebih bersifat orientasi seksual yang kompleks. ${ }^{12}$ Salah satu yang menjadi pokok yang kompleks adalah pokok persoalan berkaitan dengan apa yang menyebabkan ada perilaku (orientasi) seksual Lesbian, Gay dan Biseksual. ${ }^{13}$

Berkaitan dengan apa yang menyebabkan perilaku LGBT ini, muncul pandangan bahwa LGBT ini disebabkan oleh pembawaan Genetika yang tidak dapat ditolak. Ilmuwan pertama yang memperkenalkan teori "Gen Gay" adalah Magnus Hirscheld dari Jerman pada 1899, yang menegaskan bahwa homoseksual adalah bawaan. Dia kemudian menyerukan persamaan hukum untuk kaum homoseksual.

Pada 1991, peneliti Dr.Michael Bailey dan Dr.Richard Pillard melakukan penelitian untuk membuktikan teori tersebut. Mereka meneliti pasangan saudara: kembar identik, kembar tidak identik, saudara-saudara biologis dan saudara-saudara adopsi; salah satu di antaranya adalah seorang gay. Riset tersebut menyimpulkan adanya pengaruh genetik dalam homoseksualitas. Terdapat 52\% pasangan kembar identik dari orang gay berkembang menjadi gay. Hanya $22 \%$ pasangan kembar biasa yang menunjukkan sifat itu. Saudara biologis mempunyai kecenderungan 9,2\%, dan saudara adopsi 10,5\%. Namun gen di kromosom yang membawa sifat menurun itu tidak berhasil ditemukan.

Pada 1993, riset dilanjutkan oleh Dean Hamer, seorang gay, yang meneliti 40 pasang kakak beradik homoseksual. Hamer mengklaim bahwa satu atau beberapa gen yang diturunkan oleh ibu dan terletak di kromosom Xq28 sangat berpengaruh pada orang yang menunjukkan sifat homoseksual. Hasil riset ini meneguhkan pendapat kaum homoseksual bahwa homoseksual adalah bawaan, bukan penyimpangan sehingga

\footnotetext{
${ }^{11}$ Matthew Vines, God and the Gay Christian (New York: Convergent Books, 2014), 41

12 Seseorang bisa dikategorikan sebagai LGBT meskipun tidak menunjukkan perilaku 'waria' bahkan seorang LGBT dapat terlihat secara fisik sebagai seorang laki-laki atau perempuan yang normal.

13 Untuk persoalan transgender adalah isu tersendiri, karena golongan Gay, lesbian atau Biseksual menolak Transgender dimasukkan dalam golongan yang sama dengan mereka, sedangkan transgender juga sendiri menolak penggolongan ini.
} 
mustahil bisa diluruskan. ${ }^{14}$ Pandangan inilah yang kemudian terus dipergunakan oleh pro-LGBT untuk terus menyuarakan persamaan hak mereka.

Namun dalam perkembangannya, fakta mengenai keberadaan Gen Gay ini tidak pernah ditemukan, bahkan Hamer sendiripun mengakui hal ini bahwa tidak ada yang disebut dengan Gen Gay, sebaliknya pengaruh yang paling kuat yang mempengaruhi orientasi seksual sesorang adalah lingkungan. ${ }^{15}$

Selain itu, persoalan mengenai penyebab LGBT yang disebabkan karena genetika ini memiliki kelemahan karena LGBT ini tidak memiliki presentase yang cukup berkaitan dengan Genetika yang tersebar dalam sebuah kultur keluarga. preposisi utamanya dalam hal ini adalah bahwa jika LGBT adalah karena genetika maka seudah sepatutnya orang-orang yang ada dalam sebuah kultur yang sama akan juga memiliki kecenderungan yang sama, namun hal itu tidak dapat dibuktikan. Dalam berbagai penelitian berkaitan dengan "Gen Gay' di periode-periode sekarangpun tidak ditemukan faktor genetis mengenai ini. Jadi dalam hal ini pendapat yang menyatakan bahwa persoalan LGBT adalah karena faktor genetika tidak dapat dibuktikan. ${ }^{16}$

Selain faktor genetis, salah satu faktor yang juga dipergunakan oleh kaum proLGBT adalah pandangan bahwa persoalan LGBT adalah dikarenakan oleh karena perkembangan-perkembangan kimiawi dalam otak. Studi mengenai hal ini dilakukan oleh seorang bernama Simon LeVay, seorang proffesor dari Salk Institute for Biological Studies di San Diego, California pada tahun 1991, menurut LeVay sendiri bahwa ada perbedaan kecil dalam otak yaitu adanya neuron-neuron yang berbeda di otak heteroseksual dan homoseksual. ${ }^{17}$

Kelemahan dari pandangan ini adalah bahwa hasil dari penyelidikan tentang otak ini hanya memberikan kepada kita bahwa ada perubahan-perubahan yang terjadi di dalam otak manusia yang disebabkan oleh pengalaman-pengalaman seksual namun tidak memberikan sumbangsih otak sebagai penyebab homoseksual atau heteroseksual. ${ }^{18}$ Pada akhir penelitiannya sendiri LeVay tidak yakin bahwa otak atau perbedaan hipotalamus sendiri tidak memberikan sumbangsih apapun terhadap orientasi seksual seseorang. ${ }^{19}$

Salah satu faktor yang mempengaruhi perubahan-perubahan perilaku adalah lingkungan. Menurut penelitian yang dikembangkan oleh Whitehead dan Whitehead menunjukkan bahwa persentase homoseksualitas pada laki-laki yang dibesarkan di lingkungan perkotaan adalah 3,3 kali lebih besar dari laki-laki yang dibesarkan dalam lingkungan pedesaan, sementara yang sesuai faktor untuk homoseksualitas pada wanita

\footnotetext{
14 “Http://Www.Natureworldnews.Com/Articles/10443/20141118/Homosexuality-GeneticStrongest-Evidence.Htm,"diakses 20 Juni 2020.

15 N. and B. Whitehead Whitehead, "The 'Discovery' of the "gay Gene," accessed June 20, 2020, http://www.mygenes.co.nz/PDFs/Ch9.pdf.

16 Ibid

17 Menurut LeVay dari penelitiannya yang signifikan adalah perbedaan ukuran inti hipotalamus. Hipotalamus pada pria homoseksual diidentifikasi lebih kecil, sedangkan untuk pria heteroseksual menunjukkan bahwa berbagai ukuran dari sampel individu hampir sama

18 Hal yang luput dari pengakuan LeVay adalah bahwa otak manusia itu seperti sebuah plastik yang bersifar flexibel, sehingga dapat berubah sesuai dengan perubahan-perubahan yang terjadi. Otak bukan suatu program yang kaku melainkan flexibel, sehingga perubahan-perubahan yang terjadi pada otak heteroseksual dan homoseksual tidak dapat dijadikan sebagai acuan untuk menentukan orientasi seksual seseorang.

19 ibid
} 
adalah 2,3 kali, menunjukkan pengaruh yang sangat kuat dari lingkungan perkotaan terhadap perkembangan perilaku dan orientasi seksual seseorang.

Yang dimengerti sebagai faktor lingkungan ini, ada beberapa hal yaitu: Pertama, Perkembangan seorang anak baik secara biologis, emosional dalam lingkungan keluarga dan masyarakat cukup memberikan pengaruh yang cukup kuat berkaitan dengan perubahan-perubahan perilaku dalam pertumbuhan dan perkembangannya sebagai seorang anak yang akan bertumbuh menjadi dewasa. ${ }^{20}$

Kedua, hubungan anak dengan orang tuanya juga dapat mempengaruhi perasaan homoseksual. Menurut penelitian yang dikembangkan ditemukan bahwa perilaku homoseksual laki-laki jauh lebih mungkin berasal dari konstelasi keluarga yang melibatkan suatu hubungan yang sangat intens dengan ibu dan hubungan yang tidak sehat dengan seorang ayah.

Bahkan perilaku-perilaku dari orang tua yang memperlakukan seorang anak lakilaki seperti perempuan karena menginginkan seorang anak perempuan atau sebaliknya memberikan juga pengaruh yang cukup kuat dalam membentuk orientasi seksual seseorang. Dalam hal ini, reaksi dari rangsangan-rangsangan yang diberikan secara terus menerus menerus telah ikut membantu dalam pembentukan orientasi seksual tersebut.

Ketiga, pengalaman-pengalaman masa kecil yang disebabkan oleh pelecehanpelecehan seksual atau diskriminasi yang dilakukan dengan sengaja berkaitan dengan seksualitas pada masa kecil juga memberikan pengaruh pada perilaku dan orientasi seksual seseorang

Untuk menentukkan apakah penyebab utama dari LGBT ini tidaklah mudah, dari pemaparan diatas dapat ditarik kesimpulan sederhana bahwa orentasi seksual yang dikenal dengan istilah LGBT terjadi dari interaksi sejumlah faktor yang sudah diobservasi yakni, faktor-faktor genetik, epigenetik, biologis, hormonal, fisiologis, psikologis dan lingkungan kehidupan

Ilmu pengetahuan masih terus berhati-hati untuk memberikan kesimpulan mengenai LGBT, hal ini disebabkan karena sifat dari ilmu pengetahuan sendiri yang terus memberikan ruang untuk terus menerus dilakukan pengkajian dari berbagai perspektif, hal ini pada akhirnya tetap membiarkan perdebatan mengenai isu ini terus menerus menjadi perbincangan.

Perbincangan mengenai penyebab LGBT dari sudut pandang ilmu pengetahuan seperti yang telah dijelaskan di atas, lebih menampilkan sebuah kompleksitas ketimbang sebuah solusi untuk memberikan sebuah jalan keluar pada persoalan ini, karena pada dasarnya baik pihak pro dan anti LGBT sama-sama memiliki argumentasi untuk tetap mempertahankan pendapat mereka.

LGBT Dari sudut pandang iman dan etika Kristen, juga menghadirkan persoalan yang sama, yakni bahwa ada begitu banyak tafsir yang sangat beragam mengenai teksteks kitab suci seperti yang sudah dijelaskan pada pengantar di bab sebelumnya, bahwa tidak ada sebuah teks kitab suci yang secara per se membicarakan tentang LGBT, karena kitab suci dalam hal ini Alkitab tidak memiliki terminologi yang berhasil menggambarkan tentang LGBT itu sendiri secara kompherensif.

Dalam pembacaan mengenai penciptaan kitab suci, argumentasi yang dibangun oleh mereka yang pro-LGBT adalah bahwa kitab suci sama sekali tidak pernah berbicara mengenai LGBT, dan seandainya ditemukan sebuah pembacaan yang berkaitan dengan perilaku LGBT (Homoseksual) maka teks tersebut harus dipahami dalam konteksnya

${ }^{20}$ Ralph H. Gundlach, "Childhood Parental Relationships and the Establishment of Gender Roles of Homosexuals," Journal of Consulting and Clinical Psychology 3, no. 1 (1969): 135-53. 
dan hal ini berkaitan dengan penafsiran yang dilakukan. yang dimaksud di sini adalah bahwa ketika Alkitab membicarakan LGBT atau homoseksual adalah tidak sama dengan yang dimaksudkan pad masa kini, karena dalam konteks Alkitab, homoseksual atau LGBT lebih berhubungan dengan sebuah ritual atau penyembahan berhala dan bukan kesepakatan antara kaum LGBT yang dibangun di atas dasar cinta dan komitmen.

Misalnya, dalam pembacaan mengenai kisah penciptaan dalam kitab Kejadian, bagi kaum ataupun yang pro LGBT bahwa memang dalam teks tersebut memberikan sebuah pemahaman bahwa pernikahan yang dikehendaki adalah sebuah pernikahan yang heteroseksual tetapi itu sama sekali bukan sesuatu yang bersifat normatif, melainkan hanya merupakan sebuah dekriptif mengenai kehidupan manusia, karena dalam anggapan mereka, menikah bukan hanya untuk prokreasi.

Bahkan lebih lanjut dijelaskan bahwa sebenarnya Alkitab tidak memiliki sebuah pengajaran berkaitan dengan etika seksual, Alkitab hanya mengenal hukum kasih yang bersifat komunal, bahkan lebih jauh dalam pandangan Pro-LGBT bahwa sudut pandang untuk menolak LGBT sama sekali tidak memiliki dasar teologis apapun, alasan ini dikemukan secara jelas berdasarkan kepada pemahaman akan natur dari Tuhan itu sendiri, bahwa Tuhan adalah mahapencipta dan bukanlah Tuhan dengan Orientasi Seksual tertentu. Tuhan melampaui atau mentransendir semua Orientasi Seksual LGBT. Karena itu, Tuhan mahapencipta merangkul, memelihara, memberi kehidupan dan cinta kepada semua manusia yang memiliki orientasi seksual apapun.

Dan karena Tuhan itu mahapencipta, maka dia juga sanggup mencipta bukan hanya orientasi seksual hetero, tapi juga LGBT. Karena dia mahapencipta, maka dia juga sanggup menciptakan apapun yang tidak dikisahkan atau ditulis dalam semua kitab suci. Karena orientasi seksual LGBT itu merupakan kejadian natural yang diciptakan Tuhan, maka LGBT juga Tuhan kehendaki untuk tetap ada dan terawat dan bertahan dalam dunia ini. Barangsiapa mencintai Tuhan, mereka juga akan mencintai LGBT.

Hal ini kemudian memberikan legitimasi bahwa kekristenan sendiri seharusnya memberikan pengakuan dan penerimaan kepada kaum LGBT bahkan harus lebih jauh dari hal itu bahwa kekristenan (Gereja) juga mestinya memberikan pelayanan kepada kaum LGBT secara khusus untuk memberikan pelayanan sakramen pernikahan kepada mereka di dalam Gereja.

\section{Teologi Pernikahan Kristen Sebagai Kritik Terhadap Lgbt}

Jika dalam ilmu pengetahuan, LGBT dikaitkan dengan persoalan-persoalan biologis psikologi dan kajian ilmu-ilmu kedokteran lainnya maka dalam perspektif teologis, persoalan mengenai LGBT merupakan sebuah diskusi yang berkaitan dengan etika Kristen. Dalam sudut pandang kekristenan, LGBT merupakan sebuah persoalan etis.

Yang dimaksudkan dengan etis dalam etika Kristen adalah sebuah sudut pandang yang didasarkan kepada perspektif Alkitabiah dengan mengacu kepada pemahaman yang menyeluruh tentang wahyu Allah yang bersifat progresif. Wahyu progresif yang dimaksudkan di sini secara umum mengacu kepada karakter dari Allah yang terlihat pada saat penciptaan manusia, pada peristiwa kejatuhan manusia ke dalam dosa, sampai pada pemisahan Allah terhadap Israel dari bangsa-bangsa lain dengan pemberian 
hukum oleh Musa dan sampai pada periode ketika Yesus datang ke dunia dan juga pada periode apostolik. $^{21}$

Selain persoalan etis, LGBT juga menyinggung pada banyak isu lain, misalnya pada tataran hermeneutis yang berkaitan dengan penasiran terhadap teks-teks Alkitab yang sangat beragam, namun pada tulisan kali ini, penulis hanya akan mengamati bagian ini dari perspektif etis dan juga teologis yang secara khusus mengacu pada teologi pernikahan Kristen, karena menurut penulis persoalan LGBT harus ditarik kembali pada paradigma penciptaan yaitu bagaimana Tuhan menciptakan manusia dan memberikan perintah mengenai pernikahan.

LGBT dalam sudut pandang etis-teologis dipandang sebagai sebuah kejahatan (kekerasan) terhadap keberadaan gender laki-laki dan perempuan sesuai dengan yang Tuhan ciptakan. Bahkan dapat dikatakan bahwa secara etis-teologis Alkitabiah, LGBT adalah suatu ketidakmungkinan. Dalam narasi penciptaan juga terlihat jelas bahwa Allah ketika menciptakan Hawa (Perempuan) diambil dari tulang rusuk Adam. Proses penciptaan yang digambarkan oleh penulis kitab Kejadian ini kemudian diikuti oleh sebuah narasi yang sangat agung berkaitan dengan hubungan antara laki-laki dan perempuan yaitu pernikahan bahwa laki-laki akan meninggalkan ayah dan ibunya kemudian bersatu dengan isterinya (perempuan) dan menjadi satu daging (Kej.2:21-25).

Ungkapan 'daging' (רָָָָּ, basar) dalam terjemahan sering menyebabkan interpretasi yang tidak tepat atau tidak lengkap. Kata Ibrani ini mengacu pada lebih dari sekedar hubungan seksual. Ketika mereka bersatu dalam pernikahan, pria dan

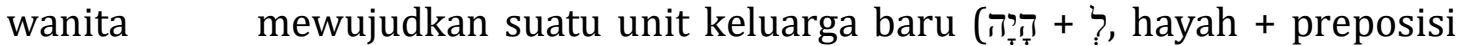
lamed berarti "menjadi"). Ungkapan "satu daging" hanya terjadi di sini dan harus ditafsirkan dalam terang ayat 23. Seorang laki-laki berkata bahwa wanita itu adalah tulang dari tulang dan daging dari dagingnya nya. Untuk menjadi seseorang "tulang dan daging" adalah untuk berhubungan dengan darah seseorang. ${ }^{22}$

Dan istilah menjadi satu daging di sini hanya dapat digunakan dalam hubungan seksual yang hetero antara laki-laki dan perempuan dalam pernikahan dan tidak ada dalam sebuah hubungan sesama jenis. Selain itu juga pada proses penciptaan perempuan yang diambil dari tulang rusuk laki-laki dengan jelas terungkap tentang hubungan keduanya.

Dari sini terlihat bahwa pernikahan yang dikehendaki oleh Allah adalah pernikahan antara seorang laki-laki dan seorang perempuan yaitu 'monogami', dan sama sekali tidak memberi ruang untuk pernikahan poligami apalagi pernikahan sejenis antara laki-laki dan laki-laki atau perempuan dengan perempuan.

Yesus Kristuspun dalam menjawab pertanyaan dari orang Farisi dan Ahli Taurat berkaitan dengan isu pernikahan dalam Matius 19 juga mengutip ide tentang menjadi satu daging dari Kejadian 2: 23- 24. Dalam penjelasan Yesus Kristus, Ia memberikan penjelasan bahwa dalam pernikahan hetero (laki-laki dan perempuan), Allah yang menyatukan sehingga dilarang untuk dipisahkan. Narasi ini juga memberikan sebuah pernyataan yang sangat gamblang soal keberadaan perempuan yang diambil dari lakilaki sehingga harus kembali kepada laki-laki yang daripadanya diambil.

Dalam konteks yang lebih luas, bahwa persatuan antara laki-laki dan perempuan melalui pernikahan dalam narasi penciptaan ini digambarkan sebagai perwujudan

${ }^{21}$ John S. Feinberg and Paul D. Feinberg, Ethics for a Brave New World (Wheaton, IL: Crossway, 2010), 51.

${ }^{22}$ NET Bible, note 74 on Gen.2:24 (Spokane, WA: Biblical Studies Press, 2006), in logos Bible Software. 
gambar dan rupa Allah. ${ }^{23}$ Perwujudan gambar dan rupa Allah tidak hanya dimiliki oleh laki-laki saja atau hanya oleh perempuan saja, tetapi gambar dan rupa Allah ini terlihat dalam diri laki-laki dan perempuan, Menurut teks di atas, manusia bukan sekadar "memiliki atau menyandang gambar Allah, melainkan adalah gambar Allah". ${ }^{24}$ Artinya, seperti yang dikemukakan Bavinck, keseluruhan pribadi manusia (laki-laki dan perempuan) adalah gambar Allah. ${ }^{25}$ Penekanan akan manusia sebagai gambar Allah dapat diamati dari struktur yang terlihat dalam penggambarannya mengenai manusia (Kej. 1:27):

Allah menciptakan manusia menurut gambar-Nya

Menurut gambar Allah diciptakan-Nya dia

Laki-laki dan perempuan diciptakan-Nya

Dua baris pertama di atas, menurut Gordon J. Wenham, dikomposisikan secara khiastik di mana "gambar Allah" merupakan penekanannya. Sementara baris ketiga menekankan bahwa baik pria maupun wanita sama-sama adalah gambar Allah. ${ }^{26}$

Dalam Kejadian 1:26-27 dan 5:1-2, dikatakan bahwa wanita diciptakan menurut gambar dan rupa Allah. Namun, menurut 1 Korintus 11:7, Paulus menyatakan bahwa pria memancarkan gambaran dan kemuliaan Allah, sementara wanita memancarkan kemuliaan pria. Apakah kedua ayat ini berkontradiksi? Tidak demikian. Penciptaan Hawa dari tulang rusuk Adam merupakan kunci untuk memahami kedua catatan yang terkesan berbeda ini. Menurut Ware, Allah menciptakan Adam dan menganugerahinya gambar-Nya secara langsung dan tanpa mediator. Namun tidak demikian dengan Hawa. Hawa tentu saja diciptakan menurut gambar Allah, namun ia mendapatkan eksistensinya dari Adam. Itulah sebabnya, 1 Korintus 11:9 bukan hanya berbicara mengenai fakta bahwa Adam diciptakan terlebih dahulu dari Hawa, melainkan juga fakta bahwa Hawa diciptakan dari tulang rusuk Adam (perhatikan preposisi ek - "keluar dari" dalam ayat ini).

Jadi ketika Paulus menyatakan bahwa wanita memancarkan kemuliaan pria, Paulus sedang membuat alusi kepada penciptaan Hawa dari tulang rusuk Adam. Selanjutnya, dalam Kejadian 5:3 dikatakan bahwa Adam memiliki seorang anak laki-laki menurut gambar dan rupa Adam. Baik ayat ini maupun 1 Korintus 11:7 mengindikasikan bahwa Allah menetapkan bahwa wanita dan keturunan Adam mendapatkan eksistensi mereka berdasarkan peran dari eksistensi Adam. Dengan

23 John H. Walton menjelaskan bahwa gambar Allah merupakan konsep teologis yang sangat penting dalam Alkitab. Meski demikian, konsep ini memiliki signfikansi kultural yang juga sangat penting untuk diketahui. Dalam konteks Near Eastern, konsep gambar Allah lebih digunakan untuk para penguasa yang berupaya mempertontonkan otoritas mereka dengan mendirikan patung-patung diri mereka di wilaha-wilayah kekuasaan mereka. Di Mesir, tempat di mana Israel pernah dijajah dan kemungkinan kitab ini ditulis pada masa Israel keluar dari Mesir, konsep gambar Allah digunakan hanya secara khusus bagi Firaun dalam pengertian kekuasaan dan hak prerogatifnya. Tampaknya, dengan menegaskan mengenai manusia (pria dan wanita) sebagai gambar Allah, penulis kitab ini ingin mengajar Israel untuk tidak mengadopsi konsep gambar Allah dalam bangsa-bangsa di sekitar mereka.John Walton, Genesis (Grand Rapids Michigan: Zondervan, 2001), 130-131.

${ }^{24}$ Herman Bavink, Reformed Dogmatics: God and Creation Volume Two, ed. ed. John Bolt (Grand Rapids Michigan: Baker Academy, 2004), 554.

25 Ibid, 554-562.

26 Gordon J. Wenham, Genesis 1-15 ( Software version of WBC, Vol.1 Dallas, Texas: Word Books Publishers, 1998). 
demikian bahwa persatuan laki-laki dan perempuan melalui pernikahan secara implisit juga merupakan wujud dari penyataan gambar dan rupa Allah dalam diri manusia. ${ }^{27}$

Dalam penyatuan antara laki-laki dan perempuan melalui pernikahan (menjadi satu daging) selain mewujudkan gambar dan rupa Allah juga adalah untuk menghasilkan keturunan (Kej.1:28). Allah menciptakan manusia juga dilengkapi dengan kemampuan untuk menghasilkan keturunan, dan hal ini hanya mungkin melalui pernikahan atau tindakan seksual antara laki-laki dan perempuan. ${ }^{28}$

Pernikahan dalam kekristenan adalah sesuatu yang sakral, karena melalui pernikahan, Allah sedang membentuk keluarga yang merupakan salah satu organisasi yang Allah dirikan sendiri selain Gereja. Melalui pernikahan itu juga, Allah menjalankan misi-Nya untuk dunia yaitu untuk mengusahakan dan memelihara alam semesta yang telah dijadikan oleh diri-Nya sendiri melalui beranak cucu dan penuhi bumi.

Dalam kejadian pasal 1, dijelaskan mengenai tujuan penciptaan manusia oleh Allah secara umum, sedangkan dalam Kejadian 2, digambarkan mengenai proses penciptaan yang lebih detail berkaitan dengan hakikat dari keberdaan manusia yang Tuhan maksudkan. Penciptaan Hawa melalui tulang rusuk Adam sedang mendemonstrasikan rencana Allah untuk pernikahan Adam yaitu sebuah pernikahan heteroseksual yang monogamy. Allah hanya menjadikan seorang 'suitable player' untuk Adam dan itu adalah seorang wanita yaitu Hawa.

Ungkapan 'suitable player' tidak memberikan indikasi bahwa Adam dalam kesendiriannya merasa tidak puas dengan keadaan tersebut atau perempuan adalah lebih rendah dari laki-laki, ${ }^{29}$ tetapi penyebutan ini dalam konteks pada saat itu lebih merupakan sebuah ungkapan bahwa seorang perempuan membuat sebuah perasaan nyaman 'congenial' bagi laki-laki yang tidak di dapatkan dari binatang yang ada pada saat itu sekaligus ungkapan ini merupakan sebuah pernyataan bahwa perempuan adalah asisten bagi laki-laki, pada tataran pribadi, perempuan akan menjadi teman yang paling tepat bagi seorang laki-laki

Selain itu melalui keluarga yang dibentuk melalui pernikahan antara laki-laki dan perempuan, Allah sedang menyatakan diri-Nya secara lengkap sebagai Allah yang yang penuh kasih, karena dalam pernikahan seperti yang Allah sampaikan dalam kejadian 2:4 bahwa "seorang laki-laki akan meninggalkan ayahnya dan ibunya dan bersatu dengan isterinya, sehingga keduanya menjadi satu daging," merupakan sebuah rahasia yang

27 Pertanyaan lain yang menarik adalah bagaimana dengan orang yang tidak menikah apakah dia bukan gambar dan rupa Allah? Bagaimana dengan Yesus yang tidak menikah tetapi merupakan gambar dan rupa Allah yang paling sempurna. Yang perlu di perhatikan di sini adalah bahwa yang dimaksudkan perwujudan gambar dan rupa Allah berkaitan dengan sebuah hubungan saling mengasihi di antara seorang laki-laki dan perempuan menggambarkan sebuah bentuk saling mengasihi di antara Allah Bapa, Anak dan Roh Kudus. Lih.J. R. W. Stott, Same Sex Partnership (Grand Rapids Michigan: Revell, 1998), chapter 3. Hal lain dari penciptaan dan perintah untuk beranak cucu dan bertambah banyak di bumi ini adalah bahwa Allah melihat bahwa semua yang dijadikan ini adalah sungguh amat baik, penekanan bahasa dengan kalimat sungguh amat baik dalam kebudayaan Alkitab (Ibrani) menunjukkan bahwa apa yang Allah ciptakan ada dalam kesempurnaan menurut sudut pandang Allah sendiri.

${ }^{28}$ Matthew Vines, God and the Gay Christian, 27. Sedangkan mengenai ada pasangan hetero yang tidak memiliki anak itu adalah isu yang berbeda dengan tujuan dari penciptaan manusia secara berpasang-pasangan, dan juga isu berkaitan dengan perkembangan ilmu pengetahuan yang mengklaim dapat menghasilkan keturunan dengan tidak melalui hubungan seksual juga hanyalah sebatas hipotesis yang belum dapat dibuktikan kebenarannya. lihat: http://citizen6.liputan6.com/read/2446105/ilmuwandi-masa-depan-pria-tak-dibutuhkan-untuk-ciptakan-

bayi?utm_source=FB\&utm_medium=Post\&utm_campaign=FBcitizen 6 diakses tanggal 02 Maret 2020

${ }^{29}$ Kata Ibrani yang digunakan adalah يِّ: (Ezer), kata ini digunakan dalam Perjanjian Lama dan selalu digunakan untuk Allah sebagai penolong misalnya dalam Kel 18:. 4; Maz. 20: 2; 33:20; $70: 5 ; 115: 9$ 11; 121: 1-2; $146: 5$ 
besar (Ef.5:32) karena melambangkan antara Kristus dan Gereja. Jadi pernikahan heteroseksual yang monogami merupakan sebuah perlambangan akan hubungan Gereja sebagai pengantin perempuan dan Kristus sebagai mempelai laki-laki

Pandangan Alkitab ini didukung juga oleh pandangan biologis bahwa ada perbedaan yang sangat mencolok dalam struktur tubuh manusia. Di mana untuk beranak cucu, Tuhan sudah memperlengkapi laki-laki dengan kemampuan untuk menghasilkan sperma sebagai benih yang akan menghasilkan keturunan dan kepada perempuan sel telur (ovum) yang berfungsi sebagai tempat untuk meletakkan benih (sperma) tersebut. Laki-laki tidak mungkin menghasilkan sel telur dan sebaliknya perempuan tidak akan menghasilkan sperma, sehingga yang Tuhan kehendaki melalui proses penciptaan dengan perintah untuk beranak cucu adalah persatuan laki-laki dan perempuan melalui pernikahan dan bukan pernikahan sesama jenis.

Jika demikian, dari sudut pandang teologis, bahwa yang menjadi penyebab utama dari adanya LGBT baik secara perilaku maupun orientasinya adalah peristiwa kejatuhan manusia ke dalam dosa (Kej.3 bnd Rm.5:12) karena pada proses penciptaan pertama, Allah telah menciptakan semuanya baik adanya.

Peristiwa kejatuhan manusia ke dalam dosa yang dilukiskan oleh Alkitab memberikan gambaran yang sangat jelas bahwa dosa telah merusak tatanan ciptaan yang telah Allah jadikan. Dalam peristiwa kejatuhan itu telah terjadi kerusakan dalam banyak aspek yang ditandai dengan rusaknya/ putusnya hubungan manusia dengan Allah, manusia dengan sesama dan manusia dengan lingkungan sekitarnya, dan hal ini dibarengi dengan apa yang disebut dengan kerusakan total yaitu bahwa gambar dan rupa Allah dalam diri Allah mengalami kerusakan yang menyeluruh. ${ }^{30}$ Ini tergambar secara jelas dalam Kejadian 6:5 "... bahwa kejahatan manusia besar di bumi dan bahwa segala kecenderungan hatinya selalu membuahkan kejahatan semata-mata".

Berdasarkan kepada kesaksian Alkitab ini terlihat bahwa manusia tidak pernah dapat melakukan kebaikan secara fundamental untuk menyenangkan Allah. ${ }^{31}$ Ini berarti bahwa dalam berbagai segi terutama secara moral, manusia telah gagal mencapai kesempurnaan yang Allah kehendaki, terutama dalam hubungan manusia dengan sesama, manusia mulai saling menyakiti dan terlebih lagi memiliki sikap yang tidak seharusnya dalam hubungan dengan sesamanya.

Manusia telah kehilangan orientasi hidupnya, dari yang seharusnya memuliakan Allah menuju kepada kehidupan yang melawan Allah dan berusaha membebaskan diri dari hukum-hukum dan perintah Allah sejak awal manusia diciptakan dan salah satunya adalah melawan perintah Allah dalam hal seksualitas. ${ }^{32}$

Dalam kaitan dengan LGBT, efek kejatuhan manusia ke dalam dosa ini tidak serta merta mengakibatkan munculnya perilaku atau orientasi yang disebutkan sebagai LGBT ini, tetapi dalam perkembangannya efek kejatuhan manusia ke dalam dosa ini secara tidak langsung telah merusak orientasi kehidupan manusia yang adalah untuk bersekutu dan memuliakan Allah menjadi tindakan untuk melawan Allah, ini terlihat dalam peristiwa selanjutnya setelah kejatuhan manusia ke dalam dosa yaitu adanya pembunuhan pertama yang dilakukan oleh Kain terhadap Habel adiknya, lalu adanya pernikahan polygami dan juga melalui peristiwa penghukuman Tuhan melalui Air bah di

30 Yang dimaksud dengan kerusakan total adalah bahwa seluruh diri manusia', baik tubuh, pikiran / pengertian, perasaan, hati / hati nurani, kemauan / kehendak, tidak ada satu bagianpun yang tidak dirusak oleh dosa (Yer 17:9 Tit 1:15 Mat 15:19).

${ }^{31}$ Edwin H. Palmer, Lima Pokok Calvinisme (Surabaya: Momentum, 2005), 8.

32Stanton L. Jones, The Gay Debate (Downers Grove, Ill: InterVarsity Press, 1994), 15. 
mana salah satu yang menjadi alasan penghukuman Tuhan adalah perilaku menyimpang dari anak-anak Allah dalam hal pernikahan.

Ketika manusia itu mulai bertambah banyak jumlahnya di muka bumi, dan bagi mereka lahir anak-anak perempuan, maka anak-anak Allah melihat, bahwa anakanak perempuan manusia itu cantik-cantik, lalu mereka mengambil isteri dari antara perempuan-perempuan itu, siapa saja yang disukai mereka.Berfirmanlah TUHAN:"Roh-Ku tidak akan selama-lamanya tinggal di dalam manusia, karena manusia itu adalah daging, tetapi umurnya akan seratus dua puluh tahun saja." (Kejadian 6:1-3)

Memang dalam ayat ini belum tercatat secara jelas apakah ada perilaku menyimpang dalam pernikahan yang dilakukan namun secara tidak langsung memperlihatkan bahwa sebuah pernikahan yang hanya dilandasi oleh hawa nafsu (perhatikan ungkapan 'siapa saja yang disukai') dan bukan berdasarkan kepada apa yang Tuhan kehendaki. Secara sederhana terlihat bahwa salah satu pengaruh dari dosa yang cukup besar dan telah menjadi sebuah kejahatan yang serius di hadapan Allah adalah perilaku yang tidak benar dalam kehidupan secara khusus pada perilaku dalam sebuah pernikahan.

Juga dalam kisah Sodom dan Gomora ${ }^{33}$ penghukuman Tuhan dinyatakan kepada kota ini karena perilaku mereka yang jahat dan berdosa kepada Allah dengan menunjukkan indikasi tentang perilaku menyimpang dalam hubungan seksual

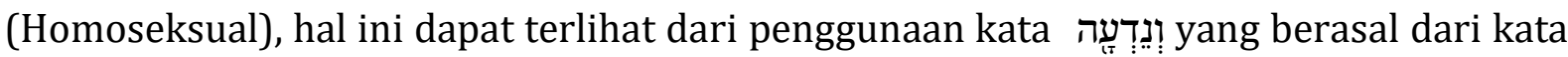
ידע (Kej 19:5) yang penggunaannya di dalam Alkitab ${ }^{34}$ selalu merujuk kepada hubungan seksual mengindikasikan dengan jelas mengenai dosa homoseksual (bnd Yudas 7) ${ }^{35}$

Dalam sejarah Israel ada setidaknya enam (6) pelanggaran atau dosa yang berkaitan dengan pernikahan yaitu (1) Poligami yang bertentangan dengan hakikat penciptaan Allah yaitu monogami (2) perceraian (3) perzinahan (4) homoseksualitas dikembangkan sebagai perilaku menyimpang memberontak terhadap desain Pencipta perkawinan heteroseksual; (5) sterilitas menjadi masalah yang diberikan hubungan perkawinan tanpa karakteristik kesuburan dari pola asli Allah; dan (6) dilusi perbedaan gender.

Pemberian hukum Allah kepada bangsa Israel lewat Musa merupakan gambaran tentang bagaimana seharusnya bangsa Israel untuk hidup berkenan kepada Allah dalam kekudusan terutama berkaitan dengan perilaku seksual dan pernikahan (Imamat 18: 22 dan 20:13). Hukum-hukum ini jugalah yang membedakan antara bangsa Israel dan bangsa-bangsa lain yang tidak mengenal Allah yang benar. Perilaku-perilaku penyembahan berhala yang dibarengi dengan tindakan atau perilaku seksual yang

${ }^{33}$ Meskipun ada banyak perdebatan mengenai kisah ini, karena ada yang beranggapan bahwa hukuman Tuhan kepada Sodom dan Gomora bukan karena homoseksual melainkan karena penduduk Sodom dan Gomora yang bertindak tidak ramah kepada tamu atau orang asing di negeri mereka. (Yeh. 16:49)

34 Perjanjian Lama menggunakan kata ini sebanyak 944 kali, dan 57 diantaranya digunakan dalam kitab Kejadian, Musa menggunakan kata ini selalu merujuk kepada hubungan seksual

35 "Pada dasarnya kata ידע' selalu digunakan dalam relasi antara laki-laki dan perempuan dalam kitab Kejadian dan selalu menunjuk pada hubungan seksual (Lih Kej. 4:1, 17, 25; 19:8; 24:16; 38:26). Hal ini semakin diperkuat dengan ketika Lot merujuk pada kedua anaknya yang belum mengenal/ bersentuhan dengan laki-laki (19:8) 
menyimpang dari awal penciptaan manusia adalah kekejian di hadapan Tuhan yang akan mendatangkan penghukuman kepada bangsa-bangsa tersebut.

Dalam Perjanjian Baru, Yesus dengan jelas mengambil prinsip pernikahan dari Kejadian 2, tentang bagaimana hubungan antara laki-laki dan perempuan dan sama sekali tidak memberikan 'ruang' kepada perilaku menyimpang dalam pernikahan (perzinahan) dan apalagi perilaku seksual yang menyimpang (lih. Mat.19:1-12).

Paulus juga dengan jelas dalam Roma pasal pertama memberikan argumentasi bahwa perilaku menyimpang dalam hubungan seksual adalah perilaku perlawanan kepada Allah dan sekaligus merupakan akibat dari kejatuhan manusia ke dalam dosa (ay.24-27). Paulus juga dengan tegas dalam I Korintus 6:9 menjelaskan mengenai para pelaku tindakan homoseksual $\mu \alpha \lambda \alpha \kappa$ í $^{36}$, dan $\alpha \rho \sigma \varepsilon v о \kappa о \tilde{\tau} \tau \alpha \iota^{37}$ sebagai orang-orang yang tidak akan mendapat bagian dalam kerajaan Allah.

\section{Kesimpulan}

Secara etis teologis, LGBT merupakan akibat dari kejatuhan manusia ke dalam dosa sekaligus juga merupakan tindakan yang berdosa, dilihat dari sudut pandang penciptaan manusia pertama kali, LGBT merupakan penyimpangan karena dalam LGBT perwujudan gambar dan rupa Allah semakin dirusak, bahkan lebih dari itu, LGBT bukan hanya merupakan perlawanan secara militan terhadap design Allah berkaitan dengan pernikahan tetapi juga pemberontakan kepada perintah Allah untuk beranak cucu dan memenuhi bumi.

Pernikahan yang diajarkan dan dikehendaki oleh Allah sesuai dengan konsep Alkitab adalah pernikahan antara laki-laki dan perempuan. Allah yang sejak semula menciptakan manusia berpasangan yaitu Adam dan Hawa adalah dengan tujuan agar mereka saling melengkapi dan juga memenuhi bumi melalui beranak cucu. Dan perilaku LGBT sama sekali tidak dapat memenuhi tuntutan dan perintah Allah untuk beranak cucu dan memenuhi bumi, sehingga tidak ada alasan untuk menyetujui perilakuperilaku LGBT.

Selain itu juga, perilaku LGBT dalam konteks PB selalu diidentikkan dengan perilaku yang terjadi dalam kuil-kuil berhala dan juga merupakan salah satu ritual yang dilakukan dalam proses penyembahan berhala, semakin memberikan keyakinan bahwa perilaku LGBT adalah tidak sesuai dengan pandangan etis dan teologis dari kekristenan.

\section{Daftar Pustaka}

Palmer, Edwin H.. Lima Pokok Calvinisme. Surabaya: Momentum, 2005.

Wenham, Gordon J. Genesis 1-15. Dallas, Texas: Word Books Publishers, 1998.

Bavinck, Herman. Reformed Dogmatics: God and Creation Volume Two. Edited by ed. John Bolt. Grand Rapids Michigan: Baker Academy, 2004.

"Http://Www.Natureworldnews.Com/Articles/10443/20141118/HomosexualityGenetic-Strongest-Evidence.Htm," n.d. http://www.natureworldnews.com/articles/10443/20141118/homosexualitygenetic-strongest-evidence.htm.

\footnotetext{
${ }^{36}$ kata $\mu \alpha \lambda \alpha \kappa o$ ini diterjemahkan ke dalam bahasa Indonesia dengan banci meskipun ini agak kurang tepat karena kata ini sebenarnya memiliki arti laki-laki yang menjadikan dirinya sebagai pelacur.

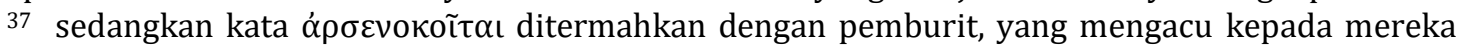
yang melakukan hubungan seksual dengan sesama laki-laki dan hal ini berkaitan dengan tindakan penyembahan berhala.
} 
Stott, J. R. W.. Same Sex Partnership. Grand Rapids Michigan: Revell, 1998.

Feinberg, John S.and Paul D. Feinberg. Ethics for a Brave New World. Wheaton, IL: Crossway, 2010.

Martin, Dale B. “Arsenokoitês and Malakos: Meanings and Consequences.” In Ethics \& Homosexuality: Listening to Scripture, edited by Robert L. Brawley. Louisville, KY: John Knox Press, 1996.

Vines, Matthew. God and the Gay Christian. New York: Convergent Books, 2014.

NET Bible, n.d.

Gundlach, Ralph H.. "Childhood Parental Relationships and the Establishment of Gender Roles of Homosexuals." Journal of Consulting and Clinical Psychology 3, no. 1 (1969): 135-53.

Jones, Stanton L.. The Gay Debate. Downers Grove, Ill: InterVarsity Press, 1994.

Sugiyono. Metode Penelitian Kombinasi. Bandung: Alfabeta, 2015.

Walton, John. Genesis. Grand Rapids Michigan: Zondervan, 2001.

Whitehead, N. and B. Whitehead. "The 'Discovery' of the "gay Gene." Accessed June 20, 2020. http://www.mygenes.co.nz/PDFs/Ch9.pdf. 